\title{
Profitability and Production Efficiency of Small-Scale Maize Production in Niger State, Nigeria
}

\author{
M.S. Sadiq*, M.T. Yakasai**, M.M. Ahmad***, T.Y. Lapkene* and \\ Mohammed Abubakar \\ *Department of Agric. Economics and Extension Techn., Federal University of Tech., Minna, Nigeria \\ **Department of Agric. Economics and Extension, Kano State University Science and Tech., Wudil, Kano, \\ Nigeria \\ *** Department of Agric. Economics and Extension, Bayero University, Kano, Nigeria
}

\begin{abstract}
This study investigates the profitability of small scale maize production in Niger state, using farm budgeting technique. Available reports on profitability studies in the state suggest little improvement among maize farmers inspite of massive investment in the sector by government. Data were collected using the multistage sampling technique, and administering structured questionnaires to a total of 200 randomly selected respondents from two LGAs of Niger State. Data collected were analyzed using descriptive statistics, net farm income analysis. The socio-economic characteristics of the respondents showed that $67 \%$ of the farmers were male, $76 \%$ were within the economically active age brackets, while $68 \%$ had non-formal education. The costs and returns analysis indicated that maize production was profitable with an average net farm income of 48 , 109.00/hectare, and a gross ratio of 0.39; a production efficiency index (2.50) per farmer further adjudged the profitability of the enterprise, that is, the returns cover the cost of production almost three times. As maize is one of the most important staple foods of great socio-economic value in the study area, an improvement in the understanding of the level of profitability can greatly aid policy makers in enhancing policies that will promote profitability in production of the crop. In addition, improved access to farmlands, acquisition of formal education, improving rural financial markets and strengthening the existing extension services were recommended to improve profitability in maize production in the area.
\end{abstract}

Keywords: Maize, Small-scale, Profitability, Socio-economics, Niger state

\section{Introduction}

In industrialized countries, maize is largely used as livestock feed and as a raw material for industrial products, while in developing countries, it is mainly used for human consumption. In sub-Saharan Africa, maize is a staple food for an estimated 50\% of the population. It is an important source of carbohydrate, protein, iron, vitamin $\mathrm{B}$, and minerals. Africans consume maize as a starchy base in a wide variety, thus, playing an important role in filling the hunger gap after the dry season (IITA, 2007a). Maize is an important food in Africa and the main ingredient in several well-known national dishes. Examples are tuwon, masara and akamu in northern Nigeria, koga in Cameroon, injera in Ethiopia and ugali in Kenya. It is also used as animal feed and as raw material for brewing beer and for producing starch (IITA, 2008).

In Nigeria, the demand for maize is increasing at a faster rate daily. This may be due to the fact that grain is being used for feeding poultry and also serve as the main food for many household (Ogunniyi, 2011). The total land area planted to maize in Nigeria is above 2.5 million hectares with an estimated yield of about 1.4 metric tones per hectare (Ogundari, 2006).

Ironically, maize as a result of the various domestic uses shows that a domestic demand of 3.5 million metric tonnes outstrips supply production of two million metric tones. However, the unfolding performance of maize can be attributed to the fact that, bulk of the country's farm, over $90 \%$ is dependent on subsistence agriculture with rudimentary farm system, low capitalization and low yield per hectare (Ogundari et al, 2006). Moreover, price fluctuation, diseases and pest, poor storage facilities and efficiency of resource utilization are the identified problems of low maize production in Nigeria (IITA, 2007b).

In view of this, profitability of small holder farms' has important implications for development strategies adopted in most developing countries where the primary sector is still dominant. An improvement in the understanding of its profitability can greatly aid policy makers in creating enhancing policies as well as in judging the efficacy of present and past reforms. The Objective of this paper is to contribute towards better understanding of small scale farmers' in Nigeria with a view of predicting profitability of maize farmers in Niger State and add to the already existing knowledge .This paper will in addition investigate socio-economic characteristics of the respondents in the study are. 


\section{Literature Review}

The major problems associated with costs and returns analysis as basis for profitability assessment according to Bernard (2003) are:

i. It does not indicate the relative importance of each of the resources in production.

ii. It is location bound and specific in applicability due to use of money as the common unit of measurement and the prevailing price of the estimates.

Despite these limitations, costs and returns analysis has been widely used in research studies.

For instance, Iheanacho (2000), employed costs-returns analysis in estimating production costs and returns for millet based cropping system in Borno State of Nigeria. Hill et al. (2001), employed it in studying the profitability of incremental generic promotion of Australian dairy products in Australia.

This method was also used by Yusuf et al.(2008), in determining the profitability of 'Egusi' melon production in Okahi local Government Area of Kogi State. Yusuf et al.(2008), discovered that 'Egusi' melon under mixed cropping system had the highest gross margin, the higher the number of crops in the mixture, the lower the gross margin. This was contrary to the work of Haruna (2008), who used gross margin analysis to determine the profitability of cassava based crops in Jama'a local Government Area of Kaduna State. He found that, the sole cassava gave the highest revenue but generated the lowest gross margin when compared with the ones under mixed cropping system. Umoh (2006), also employed this technique to estimate the profitability of urban farming and found that farming in urban area is not profitable enough to sustain an average farmer.

Yusuf et al.(2010), adopted this technique in determining the profitability of improved maize variety production in Sabon Gari Local Government of Kaduna State and found farming of improved maize variety to be profitable. Musa et al.(2010), employed costs-returns analysis in determining the profitability of soya beans marketing in Kuje Area council of Abuja. Jabo et al.(2010), used this method to determine the profitability of cowpea storage using chemical and non-chemical method and found that those using chemical storage method generated more profit than their counterparts using non-chemical method, even though, all the two cowpea method were found to be profitable ventures.

\section{Methodology}

Study Area: This study was based on the farm level data on small scale maize farmers in Niger State, Nigeria. Niger State is in the North-central part of Nigeria and lies in between longitude $3^{0} 30^{1}$ and $7^{0} 20^{1}$ east of the Greenwich Meridian and latitude $8^{0} 20^{1}$ and $11^{0} 30^{1}$ north of the equator. The land area is about 80,000 square Kilometre with varying physical features like hills, lowland and rivers. The state enjoys luxuriant vegetation with vast Northern guinea savannah found in the north while the fringe (southern guinea savannah) in the southern part of the state. The people are predominantly peasant farmers cultivating mainly food crops such as yam, cassava, maize and rice for family consumption, and markets.

Sampling Technique: The data mainly from primary sources were collected from two Local Government Areas (LGAs) which were purposively selected because of prevalence of the crop in the areas using multistage sampling technique. The LGAs are Bosso and Chanchaga LGAs. The second stage involved random sampling of five villages from each LGAs. The third stage involved a simple random selection of 20 farmers from each of the villages, thus making 200 respondents. Data were collected with use of a structured questionnaire to collect input-output data of the farmers defined within cost content. Data were also collected on the socio-economic variables such as age, educational level, farming experience of

the farmers e.t.c.

Data Analysis: The data obtained from the field were subjected to analysis using Descriptive statistics and Budget technique (net farm income).

Model Specification: Budgetary technique is expressed as:

$\mathrm{GM}=\mathrm{TR}-\mathrm{TVC} ;$ Л= GM $-\mathrm{TFC}$,

Where, $\mathrm{GM}=$ Gross Margin, $\mathrm{J}=$ profit, $\mathrm{TR}=$ Total Revenue, $\mathrm{VC}=$ Total Variable Cost, $\mathrm{TFC}=$ Total Fixed Cost. The production efficiency (PE) per maize farmer was calculated as:

$\mathrm{PE}=\mathrm{ATR} / \mathrm{ATC}$.

Where, ATR $=$ Average Total Revenue, ATC $=$ Average Total Cost.

\section{Socio-Economic Characteristics}

\section{Results And Discussion}

The socio-economic characteristics of the respondents reveals that $(76 \%)$ of the respondents were within the age bracket (19-49) defined by FAO (2008) as economically productive in a population, while $24 \%$ fall within the age group classified as dependents, with mean age of 36 years. This implies that at least two- 
thirds of the respondents were still economically active and at their productive stages; the modal class of educational level of the respondents was non-formal education (68\%), followed by formal (32\%). This suggest extension workers should do more by sensitizing farmers on the importance of formal education; $67 \%$ of the sample population are male, while only $33 \%$ are female. It can be inferred that women actively engage in farming but only on their husbands' farms. The belief in the study area is that a woman should not own a farm if she has a living husband; $73.5 \%$ of the respondents were married, while $26.5 \%$ of the sample population were not married; either single, divorced or widowed. Early marriage is a common practice in the study area. The result further indicates that farmers have varying household size. About $70 \%$ of the respondents have household size ranging from 1-10 persons, while $30 \%$ have household size of more than 10 persons. The average household size is 7 . This average is relatively fair enough considering the average farm size of 1.88ha which perhaps necessitated the use of family labour by most of the respondents in the study area. Lastly, an overwhelming majority of the farmers $(73.5 \%)$ have farming experience of equal or greater than 6 years. The average farming experience is 8 years. This means that most farmers in the study area have adequate farming experience in maize production.

Table 1: Socio-Economic Characteristics of the Respondents

\begin{tabular}{|lcc|}
\hline Socio-Economic Characteristics & Frequency & Percentage (\%) \\
\hline Age & 15 & \\
$12-18$ & 32 & 7.5 \\
$19-29$ & 73 & 16 \\
$30-39$ & 47 & 36.5 \\
$40-49$ & 33 & 23.5 \\
Less than 49 & $\mathbf{2 0 0}$ & 16.5 \\
Total & & $\mathbf{1 0 0}$ \\
Gender & 130 & \\
Male & 64 & 67 \\
Female & $\mathbf{2 0 0}$ & 33 \\
Total & & $\mathbf{1 0 0}$ \\
Marital status & 127 & \\
Married & 53 & 70.6 \\
Single & & 29.4 \\
Education & 136 & 68 \\
Non-formal & 64 & 32 \\
Formal & $\mathbf{2 0 0}$ & $\mathbf{1 0 0}$ \\
Total & & \\
Farming experience(years) & 53 & 26.5 \\
$2-5$ & 66 & 33 \\
6-10 & 32 & 16 \\
$11-15$ & 24 & 12 \\
16-20 & 8 & 4 \\
$21-25$ & 17 & 8.5 \\
26 and above & $\mathbf{2 0 0}$ & $\mathbf{1 0 0}$ \\
Total & & \\
Household size & 80 & 40 \\
1-5 & 60 & 30 \\
6-10 & 29 & 14 \\
$11-15$ & 31 & 15.5 \\
Greater than 15 & $\mathbf{2 0 0}$ & $\mathbf{1 0 0}$ \\
Total & &
\end{tabular}

Source: Field survey, 2010.

\section{Costs and Returns Analysis per Hectare}

Maize farming may not be for the purpose of only satisfying the household food need or subsistence. The farmers may be interested in selling their output to raise income. Thus, the farmers like any other entrepreneurs would be interested in the profitability of the farm enterprise. For this reason, efforts were made to determine the cost associated with maize farming and the revenue that accrues to the farmers. The results in Table 2 indicated that labour cost accounted for about $24.6 \%$ of the total cost of production. Total variable costs accounted for an overwhelming $77.9 \%$ of the total cost of production. On the average, it costs $\$ 32,079.00$ to cultivate one hectare of farm in the study area. An average of 80,188.00/ha accrues to a farmer as revenue, 
and $\mathrm{N} 55,191.00$ is left as gross margin. The average net farm income was $\mathrm{N} 48,109.00$ per hectare and percentage profit of $150 \%$ shows that maize farming is a highly profitable venture in the area. All things being equal, farmers should be able to pay back loans even at commercial bank interest rate of $60 \%$ per annum. The gross ratio of 0.39 as well as the operating ratio of 0.31 depict that maize production in the study area was profitable. Furthermore, the production efficiency index (2.50) per farmer indicates that returns exceed cost by $150 \%$ which adjudged the profitability of the enterprise in the study area. This result agreed with the findings of Ogaji (2010), who stated that the lower the gross and operating ratios, the higher the profitability of the farm enterprise and vice versa. Given the magnitude of these ratios, it can be adjudged that maize production at farm level is a profitable venture in the study area.

Table 2: Costs and Returns Analysis per Hectare

\begin{tabular}{|c|c|c|c|}
\hline Quantity/Ha & Unit Price( $(\mathbb{N})$ & $\operatorname{Cost}(¥)$ & \% of Total cost \\
\hline \multicolumn{4}{|l|}{ Variable cost } \\
\hline Cost of labour (N) $39 \mathrm{md}$ & 200/md & $7,880.00$ & 24.6 \\
\hline Cost of seeds $(\mathbf{N}) \quad 5 \mathrm{~kg}$ & 170/kg & 850.00 & 2.6 \\
\hline Cost of fertilizer (N) $111.3 \mathrm{~kg}$ & $46 / \mathrm{kg}$ & $5,121.00$ & 16.0 \\
\hline Cost of herbicides (N) 4.31t & 980/lt & $4,247.00$ & 13.2 \\
\hline Cost of transportation & & $4,349.00$ & 13.6 \\
\hline Cost of processing & & $2,550.00$ & 7.9 \\
\hline Total Variable Cost & & $24,997.00$ & \\
\hline \multicolumn{4}{|l|}{ Fixed Cost } \\
\hline Cost of renting land & & $5,000.00$ & 15.2 \\
\hline Interest on loan ( 11,850/annum) & & 948.00 & 3.1 \\
\hline Depreciation on farm tools & & $1,134.00$ & 3.8 \\
\hline Total Fixed Cost & & $7,082.00$ & \\
\hline Total cost & & $32,079.00$ & \\
\hline \multicolumn{4}{|l|}{ Returns } \\
\hline Gross income $/ \mathrm{Ha} \quad 943.39 \mathrm{~kg}$ & $85 / \mathrm{kg}$ & $80,188.00$ & \\
\hline Gross margin/Ha = GI- TVC & & $55,191.00$ & \\
\hline Net farm income $=$ GI-TC & & $48,109.00$ & \\
\hline $\mathrm{PE}=\mathrm{ATR} / \mathrm{ATC}$ & & 2.50 & \\
\hline Percent Profit & & $150 \%$ & \\
\hline Operating ratio & & 0.31 & \\
\hline Gross ratio & & 0.39 & \\
\hline
\end{tabular}

Source: Field survey, 2010.

\section{Summary and Conclusion}

Inspite of their small farm size, there is still scope or opportunity for more profit enhancement, since production efficiency index (2.50) per farmer indicates that returns covers costs almost thrice. Based on these findings, the following recommendation were made: Firstly, the low level of production made by the farmers may be attributed to low level of operation on their farm, therefore they should be encouraged to increase their size of production so as to make more profit, because the enterprise is profitable in the area. Lastly, the provision of improved rural infrastructures, promotion of rural household education, better access to credit facilities through improving rural financial markets and providing enabling polices among others are required; Awareness about the importance of education to farmers in the area should be encouraged and improved upon possibly by Non-Governmental Organisations, civil societies and other stakeholders. Lastly, an appraisal of the extension service activities in the state is suggested, so as to discover and improve on weak points, or better still modify their plan of operation to bring about better extension service delivery to the farmers.

\section{References}

[1]. Bernard, C. H. (2003). Economic Analysis of Cassava-based Cropping in Crude Oil Producing Area: A Case Study of River State Nigeria. Unpublished Ph.D Thesis, submitted to the Department of Agricultural Economics and Rural Sociology, Ahmadu Bello University Zaria, Nigeria. Pp 38-41.

[2]. Haruna, V. (2008). Economics of Cassava production in Jama'a Local Government Area of Kaduna State: A Comparative Analysis of Local and Improved Varieties. An Unpublished M.sc.Thesis, submitted to Department of Agricultural Economics and Rural Sociology, Ahmadu Bello University Zaria.

[3]. Hill, D. J., Piggott, R.R and Griffith, G. R. (2001). Profitability of Incremental Generic Promotion of Australian Diary Products. Journal of Agricultural Economics. 26: 253- 266.

[4]. Ihenacho, SA.C. (2000). Economics of Millet Production Under Different Cropping Systems in Borno State, Nigeria.Unpublished Ph.D Thesis, submitted to Department of Agricultural Economics and Rural Sociology, Ahmadu Bello University Zaria. Pp $34-$ 37. 
[5]. IITA. (2007a). Maize. IITA Research to NourishAfrica.p.1.http://http://www.iita.org/cms/details/contactus.aspx

[6]. IITA. (2007b). Doubling maize production in Nigeria in two years.www.iita.org/cms/details/research summary.aspx.

[7]. IITA (2008). Increasing maize production in West Africa.http://www.iita.org/cms/details/newssummary.aspx

[8]. Jabo, M.S. M., Maikasuwa, M. A. and Mainasara, M. (2010). Costs and Returns Analysis of Cowpea Storage (Vigna Unguiculata) Using Chemical and non-Chemical Methods. In: Nmadu, J.N and Baba, K.M. (eds). Commercial Agriculture, Banking Reform and Economic Downturn: Setting a New Agenda for Agriculture Development in Nigeria. Proceedings of $11^{\text {th }}$ Annual National conference of National Association of Agricultural Economists. Federal University of Technology, Minna, Nigeria.Pp 192-195.

[9]. Musa, S.A., Kyafi A.O., and Suleiman, M.S. (2010). Evaluation of Marketing Margin of Soya Beans in Kuje Area Council FCT Abuja, Nigeria. In: Nmadu, J.N and Baba, K.M. (eds). Commercial Agriculture, Banking Reform and Economic Downturn: Setting a New Agenda for Agriculture Development in Nigeria. Proceedings of $11^{\text {th }}$ Annual National conference of National Association of Agricultural Economists. Federal University of Technology, Minna, Nigeria.Pp 152-157.

[10]. Ogundari K. (2006). Determinants of profit efficiency among small scale rice farmers in Nigeria. A profitfunction approach. Research Journal of Applied Sciences. 1(1-4): 116-122.

[11]. Ogundari K.,S.O Ojo and I.A Ajibefun (2006). Economies of Scale And Cost Efficiency In Small Scale Maize Production: Empirical Evidence In Nigeria. Journal of Social Sciences 13(2): 131-136.

[12]. Ogunniyi L.T (2011). Determinants of Profit Efficiency Among Small Scale Maize Farmers In Oyo State, Nigeria. ARPN Journal of Agricultural and Biological Sciences 6(1): 11-17.

[13]. Umoh, G.S. (2006). Resource use Efficiency in Urban Farming: An Application of Stochastic Frontier Production Function. International Journal of Agriculture and Biology. 8 (1): $\quad 38-44$.

[14]. Yusuf, O., Haruna, V., Yusuf, H.O and Ugbabe, O.O. (2008). Factors Determining Intercropping by Small Scale Melon Production in Kogi central Zone of Kogi State, Nigeria. In: Aiyedun, E.A., Idrisa, P.O, Nmadu, J.N (eds). Agricultural Technology and Nigeria's Economic Development. Proceedings of Nigerian Association of Agricultural Economist $7^{\text {th }}-10^{\text {th }}$ October, 2008, held at University of Abuja, Nigeria Pp 120-126.

[15]. Yusuf, O., Adebayo C.O and Sani A. (2010). Economic Evaluation of Improved Maize Variety Production in Sabon Gari Local Government Area of Kaduna State, Nigeria. In: Baba K. M., Mohammed U.S., Nmadu J.N (eds) Commercial Agriculture Banking Reform and Economic Downtown: Setting a New Agenda for Agricultural Development in Nigeria. Proceedings of $11^{\text {th }}$ Annual Conference of National Association of Agricultural Economist (NAAE), 30 ${ }^{\text {th }}$ Nov. $3^{\text {rd }}$ Dec., 2010. Pp 121-135.

[16]. Ogaji, Abu (2010). "Analysis of Farm Technical Efficiency in Maize Production in Kogi State Nigeria" Un-published M. Tech. Thesis, submitted to Department of Agricultural Economics and Extension Technology, Federal University of Technology, Minna, Niger State. Pp 16-23. 